\title{
Kecerdasan Emosional dalam Mengatasi Tekanan di Masa Akhir Studi
}

\author{
Thomas Pandawa EfrataTarigan ${ }^{1 *}$, Elisabeth Sitepu ${ }^{2}$ \\ ${ }^{1}$ Sekolah Tinggi Teologi Sumatera Utara, Medan, Sumatera Utara \\ ${ }^{2}$ Universitas Darma Agung, Sumatera Utara \\ thomas3n@gmail.com
}

DOI: https://doi.org/10.47167//hharis.v3i1.36

\begin{abstract}
This paper specifically wants to give a different perspective to the final year students who are facing the final period of completion of their studies. Challenges from an economic standpoint, various difficulties when preparing the final project, difficulties in establishing good interaction and communication with the mentors, even the difficulties of students in dealing with the diversity of ways of thinking among the guiding lecturers. This often makes students depressed, feel hopeless, even stressed, which can result in the disruption of personal health. By using library research methods, researchers show that the emotional intelligence of students in overcoming stresses or difficulties at the end of the study.
\end{abstract}

Keywords: emotional intelligence; emotional maturity; student stress; student's thesis

\begin{abstract}
Abstrak
Tulisan ini secara khusus hendak memberikan sebuah sudut pandang yang berbeda terhadap mahasiswa tingkat akhir yang sedang menghadapi masa-masa akhir penyelesaian studinya. Tantangan dari sudut ekonomi, berbagai ragam kesulitan ketika sedang menyusun tugas akhir, kesulitan dalam membangun interaksi dan komunikasi yang baik dengan para pembimbing, bahkan kesulitan mahasiswa di dalam menghadapi ketidakseragaman cara berpikir antar dosen pembimbingnya. Hal ini sering sekali menjadikan mahasiswa menjadi tertekan, merasa putus asa, bahkan stress, yang dapat berakibat terganggunya kesehatan diri. Dengan menggunakan metode penelitian pustaka, peneliti menujukkan bahwa kecerdasan emosional mahasiswa dalam mengatasi tekanan atau kesulitan pada masa akhir studi.
\end{abstract}

Kata kunci: kecerdasan emosional; kematangan emosi; stres mahasiswa; tugas akhir

\section{PENDAHULUAN}

Secara umum, yang disebut sebagai mahasiswa tingkat akhir adalah mereka yang hampir menyelesaikan semua mata kuliahnya dan sedang mengambil tugas akhir (skripsi). Pada masa ini mahasiswa diperhadapkan dengan sebuah gambaran dari nilai yang akan diperoleh mereka (IPK) ketika mengakhiri studi mereka. Berkaitan dengan itu ada banyak kendala yang cenderung dihadapi, seperti adanya satu atau dua mata kuliah yang ketinggalan (belum lulus), yang dapat berdampak pada terhambatnya mahasiswa dalam syarat kelulusan. Adanya nilai yang tidak ideal atau bahkan tidak memenuhi standar kelulusan dari beberapa mata kuliah yang mengakibatkan rendahnya atau tidak maksimalnya perolehan IPK mereka. Selain itu, masalah dalam proses penyusunan tugas akhir, kesulitankesulitan ketika berhadapan dengan para dosen pembimbing bahkan penguji, perencanaan 
masa depan (langkah hidup setelah selesai studi), tuntutan keluarga agar cepat dalam menyelesaikan studinya, bahkan mungkin adanya kendala biaya dalam penyelesaian tugas akhir. Ditambah lagi, kemungkinan adanya teman sebaya yang telah lulus kuliah dan mendapat pekerjaan, sementara dirinya masih bergelut dalam dunia perkuliahan, serta masih banyaknya kendala-kendala lainnya. Permasalahan yang cukup berat tersebut tentu saja dapat menggangu konsentrasi dan kelancaran para mahasiswa dalam menyelesaikan studinya.

Dari permasalahan-permasalahan yang begitu kompleks, kemampuan mahasiswa tingkat akhir dalam menyelesaikan permasalahan tersebut berbeda-beda antara satu dengan yang lainnya. Dari hasil pengamatan di beberapa kampus ${ }^{1}$, masih ditemui mahasiswa yang gagal dalam menyelesaikan studinya, oleh karena mereka tidak memiliki kemampuan diri dalam menghadapi berbagai macam permasalahan yang muncul. Banyak mahasiswa yang kurang memiliki kecerdasan emosional yang baik dalam menghadapi berbagai macam persoalan yang ada. Bahkan kemungkinan terburuk bisa saja terjadi ketika para mahasiswa tidak memiliki kecerdasan emosional yang baik, misalnya sampai mengakhiri hidupnya akibat tidak sanggup menghadapi berbagai tekanan pada masa akhir studinya. Salah satu adanya dampak negatif dari para mahasiswa ketika menghadapi berbagai tantangan pada masa perkuliahan datang dari hasil sebuah survei yang mengejutkan yang diungkap oleh psikiater RS Hasan Sadikin Bandung yaitu dr. Teddy Hidayat Sp.KJ. (K) dalam acara World Mental Health Day di Bandung, pada Sabtu, 12 Oktober 2019 lalu. Data surveinya menyimpulkan 30,5 persen mahasiswa mengalami depresi, 20 persen berpikir serius untuk bunuh diri, dan 6 persen sudah melakukan percobaan bunuh diri. ${ }^{2}$ Survei tersebut dilakukan kepada mahasiswa semester 1 di Bandung. Faktor umum mahasiswa ingin mengakhiri hidupnya adalah tekanan akademis, ancaman drop out, keuangan, hubungan dengan dosen dan orang tua, serta hubungan asmara.

Di samping itu, adanya persepsi yang kurang tepat dari para mahasiswa tingkat akhir yang sedang menyusun skripsi. Adanya tekanan-tekanan pada masa akhir studi, membuat terjadinya pergeseran paradigma di kalangan para mahasiswa tingkat akhir. Mereka cenderung beranggapan bahwa skripsi cenderung dipersepsikan sebagai tembok penghalang masa depan mereka. Hingga akhirnya proses pengerjaan skripsi menjadi sebuah stressor $^{3}$ bagi para mahasiswa tingkat akhir yang sedang menjalaninya. Selain faktor adanya persepsi yang salah dari mahasiswa perihal skripsi, mengutip temuan dari Evi Nur Aslinawati dan Sri Umi yang menyebutkan:

Keterlambatan penyelesaian skripsi oleh mahasiswa jurusan Ekonomi Pembangunan Fakultas Ekonomi Universitas Negeri Malang, hal ini dikarenakan terdapat faktor internal dan faktor eksternal yang mempengaruhi proses penyelesaian skripsi: 1) Faktor Internal, meliputi faktor kesehatan, lemahnya motivasi, minat, kesulitan menentukan topik/permasalahan penelitian, kesulitan dalam mengumpulkan dan menganalisis data penelitian, pengalaman dalam menulis kerya tulis

${ }^{1}$ Peneliti (penulis) merupakan dosen yang mengajar juga di beberapa perguruan tinggi.

${ }^{2}$ Ikhwan Hastanto. Survei: 20 Persen Mahasiswa di Bandung Terpikir Bunuh Diri, Kesehatan Mental Isu Mendesak. https://www.vice.com/id_id/article/a35y4p/survei-20-persen-mahasiswa-di-bandung-terpikirbunuh-diri-kesehatan-mental-isu-mendesak-bagi-anak-muda-indonesia.

${ }^{3}$ Wade \& Tavris dalam buku Psikologi Jilid 2, (Jakarta: Erlangga, 2007), 6, 
ilmiah, bekerja, aktif organisasi, sertarendahnya kemampuan siswa dalam manajemen waktu ini didukung oleh 4 (empat) kecerdasan yang ada dalam diri mahasiswa. Kecerdasan yang dimaksud adalah IQ, EQ, AQ, dan SQ. Keempat cerdasan tersebut harus terpenuhi dan berjalan beriringan. Keempat kecerdasan ini juga masih juga akan mendukung mahasiswa dalam menanggapi faktor-faktor eksternal yang mempersulit proses pengerjaan skripsi; 2) Faktor Eksternal, yang dapat mempengaruhi keterlambatan penyelesaian skripsi mahasiswa, meliputi ketersediaan motivasi dari keluarga referensi, relasi antara dosen dengan maha-siswa, motivasi dari keluarga dan teman sebaya. ${ }^{4}$

Temuan tersebut merupakan sebuah bukti (perwakilan) bahwa jika mahasiswa tingkat akhir tidak bijak dalam menghadapi berbagai tantangan semasa penyelesaian tugas akhir, akan dapat berdampak buruk.

Stres memang merupakan hal lumrah yang terjadi pada setiap orang. Namun, hati-hati jika stres dibiarkan karena bisa menimbulkan berbagai gangguan kesehatan, termasuk gangguan psikosomatis. Penyakit pun bisa bermunculan atau bahkan memperparah gejala atau keluhan fisik tertentu. Permasalahan yang cukup berat tersebutjuga dapat membawa kondisi psikologis yang tertekan dan tidak nyaman.Tekanan-tekanantersebut dapat menyebabkan psikosomatis. Hal ini sesuai dengan pendapat Achmad bahwa, permasalahanpermasalahan yang menekan dapat menyebabkan gangguan fisik seperti tukak lambung, gangguan pencernaan, sakit kepala dan sebagainya. ${ }^{5}$ Sehubungan dengan itu, Kartono \& Gulo menerangkan, "psikosomatis adalah gangguan fisikakibat dari kegiatan fisiologis yang berlebihandalam mereaksi gejala emosi. Gangguan yangmenyerang fisik adalah pusing, tubuh lemas,dan keluar keringat dingin." Oleh karena itu, gangguan psikosomatis merupakan salah satu masalah kesehatan mental yang erat kaitannya dengan bagaimana pola pikir seseorang.

Menyelami lebih jauh tentang gangguan psikosomatis akan membawa kita memahami bahwa ada reaksi tubuh di luar kendali manusia. Gangguan psikosomatis terjadi ketika ada pemicu dari pikiran dan sangat dipengaruhi emosi seseorang. Maka dari itu dalam tulisan ini akan dibahas tentang bagaimana mahasiswa tingkat akhir dapat menyikapi berbagai bentuk tantangan, hambatan ataupun ketertekanan yang muncul guna mencapai keberhasilan studinya. Salah satu caranya adakah dengan mampu mengelola keberadaan emosional diri yang muncul akibat adanya tekanan-tekanan pada akhir masa studi. Kemampuan mengelola emosi ini sering disebut dengan kecerdasan emosional. Kecerdasan emosional berkaitan dengan adanya tingkat kematangan emosi yang baik ${ }^{7}$, dalam arti mahasiswa tetap dapat mengendalikan dirinya dalam menghadapi berbagai tantangan. Ketika mahasiswa tersebut tidak mampu mengatasi tekanan-tekanan yang dihadapi, di mana berbagai tekanantekanan yang muncul tersebut mampu meningkatkan frekuensi emosional diri manusia

${ }^{4}$ Aslinawati dan Sri Umi Mintarti.Keterlambatan Penyelesaian SkripsiMahasiswa Angkatan 2012(Studi Kasus Di Jurusan Ekonomi Pembangunan FakultasEkonomi Universitas Negeri Malang), Jurnal Pendidikan Ekonomi, Vol.10, No.1, 2017DOI: https://dx.doi.org/10.17977/UM014v10i12017p023.

${ }^{5}$ Achmad, S. Hubungan Antara Perilaku Asertif, Stres Dan Self Estem Dengan Depresi Pada Manusia, (Yogyakarta: Fakultas PsikologiUniversitas Gadjah Mada, 2008), hal. 37

${ }^{6}$ Kartono, K. \& Gulo, D, Kamus Psikologi, (Bandung: Pioner Jaya, 2007), 55

${ }^{7}$ Antonius Remigius Abi, "Kecerdasan Emosional Dalam Kepemimpinan Pendidikan," SOTIRIA (Jurnal Theologia dan Pendidikan Agama Kristen) 2, no. 1 (2019): 60-68. 
dengan cepat. Apabila tidak mampu dikontrol dan dikuasai akan membuat kerugian bagi manusia itu sendiri, yang akan membuat dirinya terimbas/dihantam oleh ledakan-ledakan emosinya. Hal tersebut dapat mengakibatkan seseorang tidak mampu berpikir dengan jernih dan bijak, bahkan dapat membawa efek munculnya penyakit fisik dalam dirinya.

Penelitian ini memberikan manfaat, secara khusus dalam bidang teologi, untuk memberikan semacam bingkai pengajaran kepada mahasiswa teologi dalam menghadapi berbagai persoalan yang dapat memicu efek negatif. Pendekatan konseling alkitabiah dibutuhkan demi membentuk sebuah ketahann diri mahasiswa teologi di masa akhir studi mereka. Ada peluang juga untuk mengembangkan kurikulum terkait pengembangan diri mahasiswa teologi ${ }^{8}$, sehingga nantinya mahasiswa tidak hanya kuat dalam menghadapi berbagai tekanan pada masa kuliah, bahkan setelah selesai dan berada ada dalam lingkup pelayanan.

\section{METODE PENELITIAN}

Artikel ini merupakan penelitian dengan pendekatan kualitatif literatur (library research), yang menggunakan metode analisis deskriptif. Kajian literatur atau pustaka digunakan untuk memberikan gambaran dan keterangan yang jelas tentang kecerdasan emosional mahasiswa dalam mengatasi tekanan atau kesulitan pada masa akhir studi. Pendekatan reflektif berupa kajian teologis digunakan untuk melihat peluang dan strategi apa yang dapat diterapkan untuk mengatasi persoalan mahasiswa tersebut. Itu sebabnya, analisis literatur juga menggunakan pendekatan beberapa teks dalam Alkitab.

\section{PEMBAHASAN}

\section{Stres dan Dampaknya}

Stres merupakan masalah umum yang terjadi dalam kehidupan umat manusia. Stres dapat menghampiri semua jenis usia dan tingkat status manusia. Ada banyak faktor yang dapat menjadi pemicu terjadinya stress dalam kehidupan manusia, apakah perihal ekonomi, faktor pasangan hidup, kesulitan dalam komunikasi dengan pembimbing, dll, semuanya tergantung pada lingkup kehidupan manusia itu sendiri. Dalam lingkungan akademik, stres merupakan pengalaman yang paling sering dialami oleh para siswa, baik yang sedang belajar di tingkat sekolah ataupun di perguruan tinggi. Hal tersebut dikarenakan banyaknya tuntutan akademik yang harus dihadapi, misalnya ujian, tugas-tugas, dan lain sebagainya. Sudah banyak penelitian yang menyatakan hal tersebut. Rosdiana Putri Arsaningtias melakukan penelitian terhadap 221 mahasiswa Universitas Airlangga, mengatakan:

Para mahasiswa mengalami stres dengan berbagai macam level ketika sedang mengerjakan skripsi. Ia mengatakan bahwa sebagian besar mahasiswa yang melaksanakan skripsi mengalami stresorkuat diantaranya stresor biologis $(61,1 \%)$, stresor psikologis $(48,4 \%)$, stresor sosial(43,9\%), dan stresor kultural (52\%). Sebagian besar mahasiswa yang melaksanakanskripsi mengalami stres berat $(25,8 \%)$, dan mahasiswa lainnya mengalami stresnormal $(23,1 \%)$, stres ringan $(12,7 \%)$, stres sedang $(15,8 \%)$, dan stres sangat berat $(22,6 \%)$. Sebagian besar mahasiswa

\footnotetext{
${ }^{8}$ May Rauli Simamora, Johanes Waldes Hasugian, and Agama Kristen Sekolah Tinggi Teologi Sumatera Utara, "Penanaman Nilai-Nilai Kristiani Bagi Ketahanan Keluarga Di Era Disrupsi," Regula Fidei: Jurnal Pendidikan Agama Kristen 5, no. 1 (2020): 13-24, www.ruangguru.com.
} 
mengalami stres berat $(25,8 \%)$ sedangkan sisanyamerasakan stres normal $(23,1 \%)$, stres ringan $(12,7 \%)$, stres sedang $(15,8 \%)$, dan stres sangat berat $(22,6 \%){ }^{9}$

Jika merujuk kepada pengertiannya, Kata stres berasal dari bahasa latin 'stingere'yang berarti 'keras' (stricus). Stres berdasarkan asal kata berarti keadaan atau kondisi dari tubuh terhadap situasi yang menakutkan, mengejutkan, membingungkan, membahayakan, dan merisaukan seseorang. Stres cenderung digambarkan sesuai dengan apa yangseseorang rasakan dan akibatnya bagi orang tersebut. Stres diawali dari adanya ketidakseimbangan atara tuntunan dan sumber daya yang dimiliki oleh semua individu. Pendapat ini menekankan tentang dampak dari adanya stress dalam diri seseorang yang dapat memberikan dampak secara psikis (takut, cemas, bingung).

Sementara itu, Palupi Widyastuti menekankan dampak secara fisik, yang mengatakan bahwa 'stress sebagai ketidakmampuan mengatasi ancaman yang tidak bisa dihadapi oleh mental, fisik, emosional dan spritual manusia, yang pada suatu saat dapat mempengaruhi kesehatan fisik manusia tersebut dan dapat berdampak kepada terganggunya kesehatan diri. ${ }^{10}$ Memperhatikan kedua pendapat tersebut, jelas bahwa strees yang dialami oleh seseorang dapat memberikan dampak gangguan secara psikis maupun secara kesehatan diri (fisik). Stress yang terjadi pada diri seseorang juga berdampak terhadap keberadaaan bepikir dan emosional seseorang. Dalam hal ini diperlukan suatu pengendalian diri yang baik ketika seseorang sedang mengalami stress. Tuntutan tugas dalam menyelesaikan tugas akhir (skripsi) dan berbagai situasi yang bersinggungan dengan itu, merupakan sumber stres mahasiswa umumnya, sehingga dibutuhkan keterampilan manajemen emosi, agar tidak mengakibatkan kegagalan dalam penyelesaian tugas akhir. Keterampilan tersebut lebih dikenal dengan kecerdasan emosional.

Selanjutnya, harus diperhatikan juga dampak adanya gangguan kesehatan yang disebabkan oleh stres yang tidak bisa dikendalikan dengan baik. Hal itu juga dapat mengakibatkan ganguan fisik, yang biasa dikenal dengan istilah psikosomatik. Istilah psikosomatis berasal dari bahasa Yunani, psyche yang berarti jiwa, dan soma atau badan. Psikosomatis adalah gangguan fisik yang disebabkan oleh tekanan-tekanan emosional dan psikologis atau gangguan fisik yang terjadi sebagai akibat dari kegiatan psikologis yang berlebihan dalam mereaksi gejala emosi. ${ }^{11}$ Secara khusus psikomatis ini dijelaskan oleh seorang psikolog Hubbard L. Ron, yang mengatakan:

Psikosomatik adalah gangguan fisik yang disebabkan oleh faktor-faktor kejiwaan dan sosial.Seseorang jika emosinya menumpuk dan memuncak maka hal itu dapat menyebabkan terjadinya goncangan dan kekacauan dalam dirinya. Jika faktor-faktor yang menyebabkan memuncaknya emosi itu secara berkepanjangan tidak dapat dijauhkan, maka ia dipaksa untuk selalu berjuang menekan perasaannya. Perasaaan tertekan, cemas, kesepian dan kebosanan yang berkepanjangan dapat mempengaruhi kesehatan fisiknya. Jadi, psikosomatik dapat disebut sebagai penyakit gabungan, fisik dan

\footnotetext{
${ }^{9}$ Rosdiana Putri Arsaningtias, Analisis Faktor Stresor Yang Berhubungan Dengan Stres Mahasiswa Program Studi S1 Yang Melaksanakan Skripsi diUniversitas Airlangga Surabaya. http://repository.unair.ac.id/74982/1/FKP\%20N\%20167_18\%20Ars\%20a\%20ABSTRAK.pdf.

${ }^{10}$ Palupi Widyastuti, Manajemen Stres (Jakarta: EGC, 2004), 2

${ }^{11}$ Atkinson, L, Pengantar Psikologi, (Jakarta: Erlangga, 2013), 65
} 
mental, yang dalam bahasa Arab disebut nafsajasadiyyah atau nafsabiolojiyyah. Yang sakit sebenarnya jiwanya, tetapi menjelma dalam bentuk sakit fisik. ${ }^{12}$

Dari kedua penjelasan tersebut, dapat dipahami bahwa psikosomatis diartikan sebagai gangguan fisik yang disebabkan oleh keadaan emosi yang berlebihan dan kronis dalam merespon tekanan-tekanan yang ada, seperti jantung berdebar-debar, sakit maag, sakit kepala (pusing, migrain), sesak nafas dan lesu. Sederhananya, gangguan psikosomatis bisa terjadi dalam diri setiap orang ketika seseorang itu tidak mampu mengendalikan/mengelola emosional dirinya yang muncul dari adanya berbagai tekanan yang dihadapinya.

Adapun mekanisme terjadinya psikosomatis oleh Maramis dijelaskan bahwa, ketika adasuatu stimulus emosi datang pada diri individukemudian akan ditangkap oleh panca indera, stimulus tersebut diteruskan ke sistem limbik yang merupakan pusat emosi. Dari sistem limbik, emosi disadari dan kemudian diambil keputusan-keputusan untuk mengambil tindakan-tindakan, yang kemudian diekspresikan, lalu muncul perintah-perintah dari sistem limbik yang disalurkan melalui thalamus dan hipotalamus ke organ-organ yang kemudian diekspresikan dalam berbagai bentuk perangai emosi, seperti muka yang cerah atau cemberut, muka merah atau pucat, dan menangis atau tertawa. Jika dirasa stimulus tersebut berbahaya bagi individu, maka akan menimbulkan reaksi psikis yang berwujud ketegangan emosi yang diikuti oleh aktivitas organ tubuh secara hiperaktif, misalnya detak jantung yang bertambah cepat, ketegangan otot atau meningkatnya tekanan darah. Apabila gangguan tersebut berlangsung terus-menerus maka dapat menyebabkan kerusakan pada jaringan tubuh, sehingga terjadilah psikosomatis. ${ }^{13}$

Adapun jenis-jenis psikosomatis menurut Maramis adalah:

Psikosomatis yang menyerang kulit. Gangguan psikosomatis yang sering menyerang kulit adalah alergi; psikosomatis yang menyerang otot dan tulang. Gangguan psikosomatis yang sering menyerang otot dan tulang adalah rematik, nyeri otot dan nyeri sendi; psikosomatis pada saluran pernafasan. Gangguan psikosomatis yang sering menyerang saluran pernafasan yaitu, sindroma hiperventilasi dan asma; Psikosomatis yang menyerang jantung dan pembuluh darah. Gangguan psikosomatis yang sering menyerang jantung dan pembuluh darah adalah, darah tinggi, sakit kepala vaskuler, sakit kepala vasosvastik dan migrain; Psikosomatis pada saluran pencernaan. Gangguan psikosomatis yang sering menyerang saluran pencernaan adalah sindroma asam lambung dan muntahmuntah; Psikosomatis pada alat kemih dan kelamin. Gangguan psikosomatis yang sering menyerang alat kemih dan kelamin adalah nyeri di panggul, frigiditas, impotensi, ejakulasi dini, dan mengompol; Psikosomatis pada sistem endokrin. Gangguan psikosomatis yang sering menyerang sistem endokrin adalah, hipertiroid dan sindroma menopause. ${ }^{14}$

Sederhananya semua dampak dari adanya psikosomatis tersebut berawal dari adanya strees dalam diri individu, yang tentunya bermuara dari lemahnya dalam mengendalikan dan mengelola emosional diri. Untuk itu diharapkan para mahasiswa mampu memiliki kecerdasan emosional yang baik dalam mengatasi hal tersebut. Ketika mahasiswa sudah mengalami

${ }^{12}$ Hubbard L. Ron, Dianetik, Ilmu Pengetahuan Modern Tentang Kesehatan Mental (Bandung: Pioner Jaya, 2017), 77

${ }^{13}$ Maramis, W. E. Catatan Ilmu Kedokteran Jiwa, (Surabaya: AirlanggaUniversity Press, 2004), 22-23

${ }^{14}$ Ibid., 26-27 
Psikosomatis yang mengakibatkan pada melemahnya fisik, maka tentu hal ini akan sangat menghambat dalam kelancaran proses penyelesaian skripsi. Untuk lebih jelasnya, pada topik yang berikutnya akan diuraikan apa itu sesungguhnya kecerdasan emosional serta bagaimana kecerdasan emosional tersebut mampu memberikan sebuah pencegahan atas hadirnya Psikosomatis pada para mahasiswa yang sedang menyusun tugas akhir.

\section{Kecerdasan Emosional}

Pada umumnya kecerdasan itu identik dengan sebuah kecepatan seseorang di dalam menanggapi sesuatu. Sedangkan emosi merupakan reaksi terhadap rangsangan dari luar dan dalam diri individu. Emosi berasal dari bahasa latin, yaitu kata emosi berasal dari kata 'emovere', yang berarti bergerak menjauh. Arti kata ini menyiratkan bahwa kecenderungan bertindak merupakan hal mutlak dalam emosi. Sedangkan dalam bahasa Inggris kata emosi (kata serapan) yakni 'emotion'. Kata 'emotion' digunakan untuk menggambarkan perasaan yang kuat akan sesuatu dan perasaan yang sangat menyenangkan atau sangat mengganggu $^{15}$. Dalam sejarahnya, istilah kecerdasan emosional pertama kali dilontarkan pada tahun 1990 oleh psikolog Peter Salovey dari Harvard University dan John Mayer dari University of New Hampshire untuk menerangkan kualitas-kualitas emosional yang tampaknya penting bagi keberhasilan. Salovey dan Mayer dalam Jeane Segal mendefinisikan:

Kecerdasan emosional atau yang sering disebut EQ sebagai himpunan bagian dari kecerdasan sosial yang melibatkan kemampuan memantau perasaan sosial yang melibatkan kemampuan pada orang lain, memilah-milah semuanya dan menggunakan informasi ini untuk membimbing pikiran dan tindakan. Pendapat tersebut memberikan penjelasan bahwa kecerdasan emosional itu sebagai himpunan bagian dari kecerdasan sosial yang melibatkan kemampuan memantau perasaan emosi baik pada diri sendiri maupun pada orang lain, memilah-milah semuanya, dan menggunakan untuk membimbing pikiran dan tindakan ${ }^{16}$.

Jadi, emosi merupakan salah satu aspek penting dalam kehidupan manusia, karena dapat merupakan motivator perilaku dalam arti meningkatkan ${ }^{17}$, tapi juga dapat mengganggu perilaku intensional manusia.

Kecerdasan emosional dapat dipahami sebagai kemampuan diri seorang untuk memahami keberaadaan dirinya; apa yang memotivasinya, bagaimana ia bekerja, adanya penggunaan kemampuan yang korelatif, kemampuan membentuk suatu model diri yang baik dan mampu menggunakan kecerdasan tersebut sebagai alat untuk mengatasi berbagai masalah dan tekanan yang sedang ia hadapi. Orang yang memiliki kecerdasan emosional dapat juga dikatakan sebagai individu yang memiliki kematangan secara emosional. Alkitab juga memberikan pemahaman yang sejalan dengan hal tersebut. Firman Tuhan mengatakan bahwa "hati yang gembira adalah obat yang manjur, tetapi semangat yang patah mengeringkan tulang" (Amsal 17:22). Nats ini memberikan sebuah penegasan bahwasanya emosi dan perasaan sangat dipengaruhi oleh keadaan isi hati. Ketika hati diisi penuh dengan kebencian, maka perkataan, tindakan, dan sikap akan bermuatan emosi kebencian.

\footnotetext{
${ }^{15}$ Daniel Goleman, Kecerdasan Emosi Untuk Mencapai Puncak Prestasi (Jakarta: Erlangga, 2002), 102

${ }^{16}$ Jeane Segal, Meningkatkan Kecerdasan Emosional (Jakarta: Citra Aksara, 1999), 8-9

${ }^{17}$ Lidia Susanti, "Implementasi Motivasi Belajar Model ARCS (Attention, Relevence, Confidence, Satisfaction) Siswa Kelas XI Di SMA Charis Malang," in Seminar Nasional Psikologi, 2018, 485-495.
} 
Itulah sebabnya Alkitab memperingatkan untuk selalu menjaga hati dengan sangat waspada. Emosi (perasaan) adalah sesuatu yang hakiki dari kemanusiawian, dan itu adalah bagian yang tak terpisahkan sebab Tuhanlah yang 'menanamkannya' dalam manusia kita sebagai homo sapiens, yaitu makhluk cerdas yang mempunyai rasa dan karsa. Menjadi pengikut Kristus harus menyanggupkan diri untuk mengendalikan serta menyeimbangkan emosi yang positif dan negatif, supaya bukan emosi-emosi itulah yang mengendalikan diri. Ketika seseorang mampu mengendalikan dirinya melalui suasana hati yang tidak bergejolak, akan memperlihatkan dirinya sebagai seorang pribadi yang sudah matang secara emosional. Berkenaan dengan itu Saparinah berpendapat:

Individu yang matang emosinya tidak mudahterganggu oleh rangsang-rangsang yang bersifat emosional (emosi negatif) baik dari dalam maupun dari luar dirinya. Dengan demikian individu yang kurang matang emosinya akan mudah terganggu olehr angsang-rangsang yang bersifat emosional(emosi negatif). Keadaan emosi tersebut jika dibiarkan berlangsung terus-menerus dapat menyebabkan kerusakan struktur organ yang irreversible (tidak dapat kembali sepertisemula), sehingga terjadi psikosomatis. ${ }^{18}$

Hal ini memperlihatkan bahwa sebenarnya ciri-ciri orang yang mudah terkena psikosomatis adalah orang yang tidak mampu mengendalikan emosinya. Selanjutnya, Rosyidi Hamim juga menekankan bahwa kematangan emosional seseorang dapat mengatasi seseorang dalam mengatasi berbagai kendala dalam kehidupannya. Secara lebih mendetail ia menegaskan bahwa:

Kemampuan untuk menyelesaikan masalahsecara obyektif pada seseorang dipengaruhioleh kematangan emosi yang dimiliki.Kematangan emosi adalah kemampuan untukberpikir secara realistik, dapat menerimakenyataan yang ada pada dirinya dan padaakhirnya mampu menyalurkan energinyadengan baik dan dapat mengontrol ekspresiemosinya dengan tepat. ${ }^{19}$

Kemampuan-kemampuan seperti inilah yang diduga bisa membantu mahasiswa tingkat akhir dalam meminimalkan efek negatif dari konflik-konflik kejiwaan yang kronis yang bisa menimbulkan gangguan psikosomatis. Mahasiswa yang kurang matang emosinya cenderung mengalami kesulitan dalam mengontrol dan mengekspresikan emosinya, seperti memendam emosi. Emosi yang tidak dapat tersalurkan tersebut dapat menghasilkan konflik-konflik emosional yang kronis.Apabila keadaan ini berlangsung terus menerus dalam jangka waktu yang lama akanmengakibatkan organ tubuh selalu dalamkeadaan aktif dan menjadi hiperaktif. Organ-organ tubuh tersebut akan mengalamikerusakan yang bersifat irreversible yang padaakhirnya dapat menyebabkan psikosomatis.

\section{Kecerdasan Emosional dalam Upaya Mengatasi Stres yang Memicu Psikosomatis}

Sebagaimana sudah dijelaskan sebelumnya, bahwa strees dapat mengakibatkan gangguan baik secara psikis maupun fisik terumata dalam hal gangguan kesehatan (psikosomatis). Dalam nuansa masa penyusunan tugas akhir, mahasiswa diperhadapkan dengan berbagai tantangan dan tugas-tugas akhir yang dikejar dengan sebuah deadline yang mendesak untuk dituntaskan. Ditengah tekanan tersebut, keberadaan ekonomi sebagai pen-

\footnotetext{
${ }^{18}$ Saparina S, Markam. Psikologi Diri (Jakarta:Rineka Cipta, 2011), 77-78

${ }^{19}$ Rosyidi Hamim, Psikologi Kepribadian; Paradigma Psikoanalisa (Surabaya: Jaudar Press, 2015), 55
} 
dukung dan juga problematik-problematik lainnya dapat memicu ketidakstabilan diri yang dapat menyebabkan stress, sakit penyakit, bahkan hal ditakutkan juga bisa terjadi, semisal putus kuliah dan bahkan bunuh diri. Maka dari itu dengan adanya kecerdasan emosional yang baik diharapkan para mahasiswa mampu menjadi the winner dalam mengatasi berbagai macam masalah/tekanan yang dia hadapi.

Semakin tinggi tingkat kematangan emosi padamahasiswa tingkat akhir maka psikosomatis yang dialami cenderung semakin rendah. Sebaliknya, semakin rendah tingkat kematangan emosi pada mahasiswa tingkat akhir, maka psikosomatis yang dialami cenderung semakin tinggi. Kecedasaan emosional merupakan salah satu faktor yang turut menentukan psikosomatis yang dialami oleh mahasiswa tingkat akhir. Mahasiswa yang memiliki kecerdasan emosi yang baik akan mampu menerima keadaan baik diri sendiri maupun orang lain, tidak impulsif, dapat mengontrol dan mengekspresikan emosi secara baik, bersikap sabar serta memiliki tanggung jawab yang baik. Tingkat kecerdasan emosi yang cenderung tinggi akan meminimalkan efek negatif dari konflik kejiwaan yang kronis yang dapat menimbulkan gangguan psikosomatis, yaitu gangguan fisik yang disebabkan oleh tekanan-tekanan psikologis atau gangguan fisik yang terjadi akibat dari kegiatan fisiologis yang berlebihan dalam mereaksi gejala emosi mahasiswa tingkat akhir yang telah matang emosinya dapat berpikir secara objektif.

Dengan demikian, kemungkinan terjadinya konflik dengan orang lain dapat dikurangi, sehingga tingkat stress dapat diturunkan dan psikosomatis dapat berkurang Selain itu mahasiswa juga mampu memberikan tanggapan atau respon secara tepat terhadap masalah yang dihadapi sehingga permasalahan dapat terselesaikan sebelum timbul konflik kejiwaan yang dapatm enimbulkan stres tingggi disertai keluhan fisik yang mengarah pada psikosomatis seperti gangguan kulit, gangguan saluran pencernaan, gangguan pada saluran pernafasan, gangguan pada jantung dan pembuluh darah, gangguan pada alat kelamin dan kemih, serta gangguan pada sistem endokrin. Individu yang memiliki kecerdasan emosional yang baik akan mampu mengekspresikan emosinya dengan tepat, tidak meledakkan begitu saja namun menunggu saat dan tempat yang tepat untuk mengungkapkannya dengan caracara yang lebih diterima, sehingga emosinya dapat tersalurkan dan tidak berpengaruh terhadap kondisi fisik secara nyata (psikosomatis).

Kecerdasan emosional yang baik juga ditandai dengan sifat yang tidak mudah frustrasi. Hal ini dapat menumbuhkan harapan dan motivasi yang tinggi. ${ }^{20}$ Hal ini akan menyebabkan kondisi yangtidak mudah cemas, stres, dan depresi. Selanjutnya jika beban stres rendah, makakecenderungan psikosomatis akan semakinrendah. Berbeda dengan mahasiswa tingkat akhir yang memiliki tingkat kematangan emosi yang rendah, mereka cenderung mengalami kesulitan dalam menyalurkan emosi yang ada pada dirinya. Dengan demikian dapat dimengerti bahwa, kecerdasan emosional sangat diperlukanoleh mahasiswa tingkat akhir untuk mengatasi permasalahan yang dihadapi agar tidak berdampak pada

${ }^{20}$ Lidia Susanti and Carla Imbiri, "Implementasi Motivasi Model ARCS (Attention, Relevance, Confidence, and Satisfaction) Dalam Pembelajaran Pendidikan Agama Kristen," DUNAMIS: Jurnal Teologi dan Pendidikan Kristiani 4, no. 2 (2020): 254-263. 
psikosomatis. Kecerdasan emosi juga dapat distimulasi dengan pendekatan spiritual, yang dalam hal ini peran teologi akan mengisi banyak porsi.

\section{KESIMPULAN}

Adanya kecerdasan emosional yang baik dalam diri seseorang akan membawa seseorang secara personal dapat menerima suatu keadaan atau kondisi dengan memunculkan emosi yang sesuai dengan apa yang terjadi padanya tanpa berlebihan atau meledakledak. Seseorang yang kurang matang secara emosi kurang mampu mengendalikan emosi sesuai dengan situasi dan kondisi yang dihadapi. Adanya kematangan dalam mengontrol emosional itu dapat dilihat dengan cara menumbuhkan keyakinan diri yang kuat bahwa segala permasalahan pasti akan mampu diatasi. Pendekatan spiritual sangat penting dalam membangun kecerdasan emosional, dengan memandang pada prinsip bahwa Tuhan tidak memberikan pencobaan yang melampaui kekuatan seseorang (1 Kor. 10: 13). Kekuatan rohani penting untuk membangun kemampuan kecerdasan emosi seorang mahasiswa dalam menghadapi persoalan studi di tingkat akhir. Dengan adanya kemampuan dalam mengontrol dan mengarahkan emosi secara tepat diharapkan mempunyai perilaku yang sesuai dengan normasosial, maka seseorang tersebut dapat dikatakan matang secara emosi. Individu yang cerdas secara emosional akan cenderung memiliki mental yang kuat, serta dapat dikatakan sebagai individu yang dewasa dalam berpikir dan bertindak, sehingga tidak lagi menampilkan pola-pola emosi seperti kanak-kanak. Penelitian ini diharapkan ke depan akan menstimulasi sebuah kajian tentang membangun kecerdasan emosi secara biblikal dengan pendekatan analisis teks.

\section{REFERENSI}

Abi, Antonius Remigius. "Kecerdasan Emosional Dalam Kepemimpinan Pendidikan." SOTIRIA (Jurnal Theologia dan Pendidikan Agama Kristen) 2, no. 1 (2019): 60-68.

Achmad, S. 2008, Hubungan Antara Perilaku Asertif, Stres Dan Self Estem Dengan Depresi Pada Manusia. Yogyakarta: Fakultas Psikologi Universitas Gadjah Mada Arsaningtias, Rosdiana Putri. 2017, Analisis Faktor Stresor Yang Berhubungan Dengan Stres Mahasiswa Program Studi S1 Yang MelaksanakanSkripsi di Universitas AirlanggaSurabaya.http://repository.unair.ac.id/74982/1/FKP\%20N\%20167 18\%20Ars\%2 0a\%20ABSTRAK.pdf.

Goleman, Daniel. 2002, Kecerdasan Emosi Untuk Mencapai Puncak Prestasi.Jakarta: Erlangga

Gulo, D \& Kartono K. 2007, Kamus Psikologi. Bandung: Pioner Jaya

Hamim, Rosyidi. 2015, Psikologi Kepribadian; Paradigma Psikoanalisa.Surabaya: Jaudar Press

Hastanto, Ikhwan. 2019, Survei: 20 Persen Mahasiswa di Bandung Terpikir Bunuh Diri, Kesehatan Mental Isu Mendesak. Dipost pada 14 Oktober 2019 pada laman: https://www.vice.com/id_id/article/a35y4p/survei-20-persen-mahasiswa-di-bandung-terpikirbunuh-diri-kesehatan-mental-isu-mendesak-bagi-anak-muda-indonesia.

Hubbard L. Ron. 2017, Dianetik, Ilmu Pengetahuan Modern Tentang Kesehatan Mental.Bandung: Pioner Jaya

L, Atkinson. 2013, Pengantar Psikologi.Jakarta: Erlangga

Maramis, W. E. 2004, Catatan Ilmu Kedokteran Jiwa. Surabaya: Airlangga University Press 
Mariyanti, Sulis. Seminar Psikologi dan Kemanusiaan Dengan Topik Model Strategi Coping Penyelesaian Studi sebagai Efek Stressor Serta Implikasinya Terhadap Waktu Penyelesaian Studi Mahasiswa Universitas Esa Unggul: Studi pada Mahasiswa Universitas Esa Unggul yang telah Menyelesaikan Skripsi. Jurnal Psikologi, Fakultas Psikologi -Universitas Esa Unggul Jakarta, 2015, hal. 18

Markam, Saparina S. 2011, Psikologi Diri. Jakarta: Rineka Cipta

Rauli Simamora, May, Johanes Waldes Hasugian, and Agama Kristen Sekolah Tinggi Teologi Sumatera Utara. "Penanaman Nilai-Nilai Kristiani Bagi Ketahanan Keluarga Di Era Disrupsi." Regula Fidei: Jurnal Pendidikan Agama Kristen 5, no. 1 (2020): 1324. www.ruangguru.com.

Segal, Jeane. 1999, Meningkatkan Kecerdasan Emosional. Jakarta: Citra Aksara

Susanti, Lidia. "Implementasi Motivasi Belajar Model ARCS (Attention, Relevence, Confidence, Satisfaction) Siswa Kelas XI Di SMA Charis Malang.” In Seminar Nasional Psikologi, 485-495, 2018.

Susanti, Lidia, and Carla Imbiri. "Implementasi Motivasi Model ARCS (Attention, Relevance, Confidence, and Satisfaction) Dalam Pembelajaran Pendidikan Agama Kristen." DUNAMIS: Jurnal Teologi dan Pendidikan Kristiani 4, no. 2 (2020): 254263.

Wade \& Tavris. 2007, Psikologi. Jakarta: Erlangga

Widyastuti, Palupi.2004, Manajemen Stres.Jakarta: EGC 